\title{
PENERAPAN ACTIVITY BASED COSTING SYSTEM DALAM PENENTUAN HARGA POKOK TARIF PENYEWAAN JASA KENDARAAN PADA PT. SERASI AUTORAYA
}

\author{
Fricilia Kindangen ${ }^{1}$, Jenny Morasa ${ }^{2}$, Lidia M. Mawikere ${ }^{3}$ \\ 1,2,3 Jurusan Akuntansi, Fakultas Ekonomi dan Bisnis Universitas Sam Ratulangi, Jl. Kampus Bahu, Manado, \\ 95115, Indonesia \\ Email : friciliakind@gmail.com
}

\begin{abstract}
Activity Based Costing $(A B C)$ is a simple calculation system to determine the cost of a product / service on the basis that it is the activity that causes the cost to arise, not from the product and the product that consumes the activity, the indirect costs can be determined through the activity it passes and the costs for each activity are then charged the product on the basis of consumption of each product in the activity. The purpose of this study was to determine the application of the cost of vehicle rental using Activity Based Costing method at PT Serasi Autoraya. This study uses descriptive analysis method, which is done by interviews and documentation. The results showed a comparison between the methods used by PT Serasi Autoraya and the application of Activity Based Costing System. For the calculation of the cost of the rental vehicle using Activity Based Costing System, namely for the type of Avanza car $R p$. 3,710,271 and for Innova cars $R p$. 6,567,413. There is a lower price difference between the calculation of PT Serasi Auotaraya and the results of calculations using Activity Based Costing System, namely for the Avanza Rp. 1,864,750 and for the Innova type there is a difference in the price of $R p .1,313,728$.
\end{abstract}

Keywords: cost of rental service vehicle, Activity Based Costing System

\section{PENDAHULUAN}

Perusahaan mempunyai tujuan dalam melakukan pertumbuhan dan meningkatkan profitabilitasnya. Persaingan bisnis di Indonesia sekarang ini semakin ketat, apalagi dalam perkembangan dunia yang semakin pesat mengakibatkan perusahaan dituntut harus lebih cermat dalam mengatur strategi dan inovasinya. Persaingan bisnis yang terjadi ternyata bukan hanya di bidang manufaktur atau industri tetapi juga terdapat pada bidang usaha perdagangan dan pelayanan jasa. Perhitungan harga pokok produk atau jasa yang akurat sangat penting untuk menjadi suatu gambaran dalam melihat kemampuan suatu organisasi perusahaan dalam memproduksi barang dan jasa. Oleh karena itu, pengambilan keputusan dari pihak manajemen mengenai halnya dengan penelusuran biaya yang tepat berpengaruh pada penetapan harga suatu produk atau jasa.

Harga pokok tentunya mempunyai peranan yang sangat penting dalam menentukan harga jual produk atau jasa. Sistem Activity Based Costing menyediakan informasi biaya yang menghasilkan harga pokok lebih akurat sehingga dapat menjadi salah satu motivasi manajemen dalam mengelola biaya suatu perusahaan secara efesien serta menentukan kebijakan dalam meningkatkan profitablitasnya. Activiy Based Costing merupakan suatu metode perhitungannya yang sederhana dalam menentukan harga pokok atau jasa bahwa penyebab timbulnya biaya berdasarkan kegiatan atau aktivitas-aktivitas dalam perusahaan.

PT. Serasi Autoraya merupakan perusahaan yang bergerak dibagian jasa penyewaan kendaraan mobil. Perlindungan asuransi, adanya unit pengganti, service car, dan perawatan kondisi kendaraan yang dijaminkan perusahaan adalah contoh suatu strategi dalam menarik konsumen. Kualitas pelayanan dan harga sewanya juga sangat perpengaruh terhadap 
kepuasan para konsumen. Tujuan dilakukannya penelitian ini adalah untuk mengetahui bagaimana hasil dari penerapan menggunakan Activity Based Costing System dalam penentuan harga pokok tarif penyewaan jasa kendaraan pada PT. Serasi Autoraya.

\section{TINJAUAN PUSTAKA}

Pengertian Akuntansi. Menurut Marshall Romney (2014 :11) Akuntansi ialah proses pengidentifikasi, pencatatan, pengumpulan dan penyimpanan data yang berhubungan dengan keuangan serta proses pengembangan, pengukuran dan komunikasi.

Pengertian Akuntansi Manajemen. Menurut Hansen dan Mowen (2013 :7) Akuntansi Manajemen merupakan proses pengidentifikasi, menganalisa dan mengumpulkan data serta melaporkan informasi mengenai kondisi perusahaan yang bermanfaat bagi yang memerlukan informasi tersebut yaitu para pengguna internal mengenai halnya dengan perencanaan suatu kegiatan atau organisasi, mengendalikan dan tindakkan dalam mengambil keputusan demi kemajuan suatu perusahaan.

Pengertian Akuntansi Biaya. Menurut Carter (2013 :11) mengungkapan bahwa Akuntansi Biaya sebagai alat yang diperlukan untuk melengkapi manajemen yang berhubungan dengan suatu perencanaan dan pengendalian, serta membuat keputusan yang cermat dan bersifat strategis. Dapat juga diartikan sebagai suatu proses pencatatan dan penggolangan dari peringkasan biaya-biaya yang terjadi didalam perusahaan.

Pengertian Activity Based Costing. Menurut Mulyadi (2014 :40) ABC yaitu suatu sistem akuntansi dalam memberikan informasi biaya yang berfokuskan pada aktivitasaktivitas untuk memungkinkan dalam melaksanakan pengolahan aktivitas didalam perusahaan yang menjadi penyebab timbulnya biaya. Sistem informasi ini berfokus pada aktivitas-aktivitas yang terjadi dalam suatu perusahaan dan menimbulkan biaya untuk menghasilkan produk atau jasa.

Manfaat Activity Based Costing. Menurut Dunia dan Abdullah (2013 : 328) bahwa manfaat dari $A B C$ ialah dapat membantu para manajemen untuk menyajikan pengukuran biaya yang lebih akurat serta mengidentifikasi jika terjadi ketidakefisienan dalam proses produksi baik dalam per departemen, per produk ataupun per aktivitas. Membantu untuk memudahkan manajer dalam pengambilan keputusan tentang penerapan harga pokok karena perhitungan dan pengendalian biaya menjadi lebih akurat.

Keungulan Activity Based Costing. Suatu pengkajian dalam sistem $A B C$ meyakinkan para manajemen untuk meningkatkan ketelitian dalam perincian biaya menjadi lebih baik, sehingga mereka dapat berusaha untuk meningkatkan sumber daya suatu perusahaan dan memfokuskan pada sifat rill dari perilaku biaya dalam membantu mengurangi biaya. $A B C$ juga membantu para manajer dalam pengambilan keputusan untuk kemajuan suatu organisasi perusahaan.

Activity Based Costing System pada Perusahaan Jasa. Penerapan $A B C$ pada perusahaan jasa terdapat karakteristik yang dimiliki oleh perusahaan jasa tersebut. Menurut Sulastiningsih dan Zukufli (2013: 67), karakteristik yang dimiliki perusahaan jasa, yaitu aktivitas organisasi jasa sangat bervariasi, sehingga pengendalian aktivitas pada permintaan jasa sulit didefinisi dan output untuk organisasi jasa sulit didefinisikan dan sulit diukur.

Klasifikasi Aktivitas Sistem Activity Based Costing. Mengklasifikasikan atau menggolongkan aktivitas dalam penerapan sistem $A B C$ termasuk dasar dalam metode perhitungan atau merupakan cara untuk menghasilkan informasi biaya yang lebih akurat. Klasifikasi aktivitas yang terdapat dalam sistem $A B C$ terdiri dari empat jenis aktivitas, diantaranya berdasarkan uni level activities, batch level activities, product activities, level facility activities.

Mekanisme Penerapan Activity Based Costing System. Kamaruddin (2013:18) menyatakan dalam mekanisme penerapan $A B C$ System ada dua tahap. Tahap pertama, biaya 
overhead pabrik dibebankan pada aktivitas-aktivitas yang sesuai dan dikelompokkan (cost pool). Kemudian membagi jumlah dari semua biaya yang terdapat didalam cost pool tersebut dengan aktivitas yang telah diterapkan. Tarif pool ini berarti biaya per unit pemacu biaya (cost driver). Tahap kedua, membebankan biaya sumber daya kepada produk dengan menggunakan tarif kelompok. Dalam tahap ini, konsep perhitungannya perlu diperhatikan secara cermat dan teliti bahwa setiap biaya-biaya produk dihasilkan dari adanya aktivitas. Biaya-biaya pada cost pool yang telah dihitung ditelusuri ke produk menggunakan tarif pool dikalikan dengan cost driver pada masing-masing produk/jasa.

Penelitian Terdahulu. Rida Ayu Damayanti (2017), dalam penelitiannya berjudul Analisis Penerapan Metode Activity Based Costing Dalam Penentuan Tarif Harga Sewa Kamar Hotel. Hasil menunjukkan adanya selisih yang terjadi dalam perhitungan harga pokok kamar di hotel tempat penelitian tersebut ternyata lebih rendah menggunakan metode $A B C$ apabila dibandingkan dengan harga pokok menggunakan metode konvensional. Uyun Nailufar (2015), dalam penelitiannya berjudul Penerapan Activity Based Costing System Dalam Menentukan Harga Pokok Jasa Rawat Inap (Studi pada RSUD Ibnu Sina Kabupaten Gresik Tahun 2013). Hasil penelitian ini terdapat perbedaan hasil yang dilakukan peneliti mengenai perhitungan menggunakan metode tradisional dan perhitungan dengan menggunakan $A B C$ System. Hal ini disebabkan karena dasar alokasi metode tradisional dan perhitungan menggunakan $A B C$ berbeda sehingga terjadinya perbedaan hasil tersebut. Dalam metode tradisional dasar alokasinya digunakan hanya satu sedangkan ada sistem $A B C$ menggunakan empat dasar alokasi. Terjadi overcosting pada ruang perawatan dirumah sakit tempat penelitian dibagian Kelas I, VIP, VVIP dan II sedangkan pada ruang Kelas III terjadi undercosting. Carissa Carmelita (2017), dalam penelitiannya berjudul Analisis Activity Based Costing System Dalam Penentuan Harga Pokok Produksi Guna Menentukan Harga Jual Gula (Studi Kasus pada PT. PG. Kebon Agung Unit PG. Kebon Agung Kecamatan Pakisaji Kabupaten). Hasil penelitiannya menunjukkan terdapat perbedaan hasil yang dilakukan oleh peneliti antara perhitungan harga pokok produksi menggunakan akuntansi biaya tradisonal dan metode Activity Based Cositing. Produk gula mengalami overcosting sedangkan produk tetes mengalami undercosting, ini disebabkan karena saat melakukan perhitungan harga pokok dengan metode tradisional hanya membebankan pada satu cost driver saja sedangkan perhitungan dengan menggunkan $A B C$ membebankan lebih dari satu cost driver.

\section{METODE PENELITIAN}

Jenis Penelitian. Dalam penelitian ini termasuk jenis penelitian deskriptif dengan pendekatan kualitatif yang digunakan untuk menggambarkan atau menganalisis suatu hasil penelitian. Penelitian kualitatif ini secara umum cenderung menggunakan analisis dan dapat digunakan untuk penelitian tentang kondisi objek penelitian, sejarah tempat penelitian tersebut beserta tingkah laku, fungsionalisasi organisasi, aktivitas sosial yang terjadi dalam lingkup penelitian, dan lain-lain (Sujarweni, 2014).

Tempat dan Waktu Penelitian. Lokasi penelitian ini bertempat di PT. Serasi Autoraya (TRAC - Astra Rent a Car) Jalan Tololiu Supit Teling Atas Manado. Waktu penelitian yaitu pada bulan Februari sampai April tahun 2018.

Prosedur Penelitian. Prosedur penelitian dilakukan meliputi tahap-tahap penelitian yang dimulai dari mengajukan surat permohonan dari peneliti kepada perusahaan, kemudian mengumpulkan data dari hasil wawancara yang dilakukan peneliti ke pihak manajemen atau yang bersangkutan untuk merumuskan masalah yang diteliti dan menganalisis data yang diperoleh, serta mengambil kesimpulan dari hasil penelitian yang dilakukan.

Sumber Data. Sumber data yang diambil dari peneliti yaitu data primer yang merupakan sumber data yang secara langsung memberikan datanya kepada pengumpulan data yang didapatkan dari tempat penelitian tersebut dan data sekunder dan data sekunder merupakan 
sumber data yg peneliti peroleh dengan menggunakan metode tinjauan kepustakaan atau mengaskses website yang berkaitan dengan judul yang diteliti (Sugiyono, 2013).

\section{Teknik Pengumpulan Data.}

- Wawancara. Wawancara ini merupakan proses dari peneliti untuk memperoleh penjelasan dalam mengumpulkan data atau informasi dari pihak perusahaan yang diwawancarai.

- Dokumentansi. Teknik yang peneliti gunakan untuk mengambil dan mengumpulkan datadata penting melalui dokumen-dokumen dari perusahaan yang terkait dalam penelitian.

Metode Analisis. Metode analisisnya adalah metode deskriptif yang merupakan metode analisis dalam mengumpulkan data-data yang diperlukan dalam peneltian yang bertujuan untuk memberikan gambaran atau uraian mengenai keadaan yang diteliti.

\section{HASIL PENELITIAN DAN PEMBAHASAN}

\subsection{Hasil Penelitian}

Berdasarkan informasi yang peneliti peroleh dari hasil wawancara dengan pihak perusahaan bahwa PT. Serasi Autoraya tidak menggunakan sistem perhitungan Activity Based Costing, tetapi menggunakan perhitungan profit loss yang formulasi perhitungannya memakai aplikasi microsoft excel. Perusahaan ini dua devisi dalam proses penyewaan kendaraan yaitu devisi leasing yang mengakomodir untuk penyewaan 1 bulan dan devisi rental untuk sewa harian. Prosedur penyewaan kedua devisi itu berbeda. Devisi rental membutuhkan fotocopy KTP, NPWP, dan kartu kredit dari customer dikarenakan devisi rental hanya disewakan perorangan. Sedangkan devisi leasing disewakan oleh perusahaan yang berbadan hukum dan membutuhkan NPP perusahaan, KTP penandatanganan kontrak, surat akte pendirian perusahaan lengkap, alur pembayaran dari customer, surat pembukuan kena pajak, tanda daftar perusahaan, dan surat keterangan domisili. Setelah customer memasukkan syarat diatas, kemudian marketing rental akan memasukkan ke sistem dan selanjutnya akan diproses di customer master data dari head office Jakarta. Untuk proses dari devisi rental memakan waktu satu hari sedangkan devisi leasing prosesnya bisa sampai seminggu.

PT. Serasi Autoraya (TRAC - Astra Rent a Car) cabang Manado memiliki sekitar 300 lebih kendaraan yang disediakan. Terdapat juga mobil-mobil tambang berukuran $4 \times 4$, tapi masa waktu sewa untuk mobil tersebut harus 3 tahun. Rata-rata costumer yang menyewa kendaraan di TRAC berasal dari bank dan perusahaan rokok di Manado. Beberapa lembaga pemerintahan juga melakukan penyewaan kendaraan di peusahaan ini seperti Kementrian Hukum dan HAM, Badan Keuangan, Dinas Pertanian dan seluruh pemerintahan Provinsi di Gorontalo. Total karyawan TRAC cabang Manado ada 30 karyawan. Di Manado perusahaan ini mempunyai saingan, antara lain Assa Rent, Indo Rent, dan Adiatma. Untuk Assa Rent sendiri prosedurnya mirip dengan TRAC karena Assa Rent mengadopsi sistem dari TRAC. Tetapi Assa Rent memiliki harga sewa lebih murah mungkin dikarenakan karyawannya masih sedikit dan gedung yang dijadikan kantor mereka masih sewa.

Pada penelitian ini, penulis tidak menggali informasi lebih mendalam akan semua kendaraan yang disewakan. Dalam proses wawancara, penulis mengambil data penelitian yang didapat dari perusahaan hanya pada 2 jenis kendaraan yaitu Avanza dan Innova. Untuk mempermudah dalam penelitian, penulis akan meneliti harga sewa perbulan pada bulan Maret tahun 2018 beserta perhitungan jenis kendaraan Avanza dan Innova dikarenakan devisi leasing yang menagani penyewaan diatas 30 hari atau 1 bulan dibawah pengawasan dari TRAC masing-masing cabang sedangkan devisi rental yang menangani penyewaan dibawah 30 hari atau harian dikontrol dari TRAC pusat. 


\subsection{Pembahasan}

Harga Pokok Sewa Kendaraan PT. Serasi Autoraya. Berdasarkan data yang diperoleh melalui proses wawancara, peneliti dapat mengetahui bahwa PT Serasi Autoraya menggunakan perhitungan Profit Lose System dalam menghitung harga sewa kendaraan. Perusahaan melakukan sistem perhitungan tersebut dengan menggunakan Microsoft Excel. Ada 2 jenis mobil yang disewa oleh customer, yaitu Avanza dan Innova. Dalam menghitung harga sewa kendaraan, perusahaan menghitung harga OTR (on the road) pada mobil terlebih dahulu kemudian membebankan biaya lain.

Tabel 1. Harga Pokok dan Harga Sewa Kendaraan perbulan PT. Serasi Autoraya

\begin{tabular}{ccc}
\hline Jenis Kendaraan & Harga Pokok Sewa Kendaraan & Harga Sewa Kendaraan \\
\hline Avanza & Rp. 5.575 .021 & Rp. 5.600 .000 \\
Innova & Rp. 7.881 .141 & Rp. 7.900 .000 \\
\hline
\end{tabular}

Sumber data PT. Serasi Autoraya

Pada Tabel 1 tarif sewa kendaraan PT. Serasi Autoraya berpengaruh juga pada type mobil dan harga OTR (on the road). Jika type mobil berbeda, maka harga OTR berbeda dan tarif sewa akan berubah juga. Harga pokok sewa kendaraan pada jenis mobil Avanza adalah Rp. 5.575.021 sedangkan pada jenis mobil Innova adalah Rp. 7.881.141. Jumlah unit yang disewa pada bulan Maret tahun 2018 dikota Manado berjumlah 170 unit mobil, yang terbagi atas 135 unit mobil Avanza dan 35 unit mobil Innova.

Penentuan Harga Pokok Sewa Mobil Menggunakan Metode Activity Based Costing System (ABC System)

Pengidentifikasian Aktivitas. Indentifikasi ini dilakukan dengan menentukan aktivitasaktivitas yang menimbulkan biaya pada perusahaan setelah itu dikelompokkan dalam berbagai level aktivitas.

Pengklasifikasian Biaya Berdasar Aktivitas Ke Dalam Berbagai Level Aktivitas. Setelah daftar aktivitas disusun, selanjutnya adalah mengklasifikasikan aktivitas-aktivitas tersebut ke level dan biaya-biaya didalam aktivitas tersebut. Aktvitas dapat digolongkan dalam dua ketegori, yaitu unit level activity dan facility level activity.

Tabel 2. Klasifikasi Biaya ke dalam Berbagai Aktivitas per Bulan

\begin{tabular}{lr}
\hline \multicolumn{2}{c}{ Aktivitas } \\
\hline Unit Level Activity & Jumlah (Rp) \\
Gaji Karyawan & 135.000 .000 \\
Biaya Listrik & 10.000 .000 \\
Biaya Air & 7.500 .000 \\
Facilty Level Activity & \\
Perawatan & 378.250 .000 \\
Asuransi & 59.487 .212 \\
Depresiasi & 5.510 .563 \\
Total & $\mathbf{5 9 5 . 7 4 7 . 7 7 5}$ \\
\hline
\end{tabular}

Sumber data diolah

Pengidentifikasian cost driver. Mengidentifikasi cost driver dari setiap aktivitas biaya yang telah dikelompokkan menjadi langkah selanjutnya setelah aktivitas-aktivitas biaya tersebut diklasifikasikan sesuai dengan kategori aktivitasnya. 
Penetuan Tarif Kelompok per unit. Setelah pengidentifikasian cost driver, selanjutnya ialah menghitung cost pool rate dengan membaginya berdasarkan cost driver. Hal ini dapat dihitung dengan rumus: Tarif per unit cost driver $=$ Jumlah Aktivitas Cost Driver

Pembebanan Biaya ke Produk atau Jasa dengan Menggunakan Tarif Cost Driver dan Ukuran Aktivitas. Tahap selanjutnya, setiap kelompok biaya overhead ditelusuri keberbagai jenis aktivitas dengan menggunakan tarif kelompok yang dikonsumsi oleh setiap produk/jasa yaitu dengan cara biaya-biaya yang telah dibebankan pada perhitungan sebelumnya sama dengan tarif kelompok (cost pool) dikalikan dengan cost driver pada masing-masing produk/jasa. Overhead yang dibebankan dari setiap kelompok biaya ke produk dihitung dengan menggunakan rumus: $\mathrm{BOP}$ dibebankan $=$ Tarif kelompok $\times$ Unit Cost Driver yang digunakan.

Perbandingan Perhitungan Harga Sewa Kendaraan yang menggunakan Activity Based Costing System dengan Metode yang Diterapkan pada PT. Serasi Autoraya. Dari hasil yang diperoleh tersebut dapat dilihat perbandingkan antara metode yang digunakan PT Serasi Autoraya dan penerapan Activity Based Costing System pada bulan Maret tahun 2018. Untuk perhitungan Activiy Based Costing System pada jenis mobil Avanza memberikan hasil harga pokok sewa lebih rendah dibandingkan yang ditentukan oleh perusahaan PT Serasi Autoraya, yaitu dengan selisih harga Rp. 1.864.750 dan untuk jenis mobil Innova hasil perhitungan harga pokok sewa lebih rendah juga dibandingakan harga pokok sewa yang ditentukan oleh perusahaan, yaitu dengan selisih harga sebesar Rp. 1.313.728.

\section{KESIMPULAN DAN SARAN}

\subsection{Kesimpulan}

Berdasarkan hasil penelitian dan pembahasan mengenai penerapan harga pokok tarif penyewaan jasa kendaraan dapat ditarik kesimpulan bahwa :

1. Terdapat perbedaan antara harga pokok sewa kendaraan yang ditentukan oleh PT Serasi Autoraya dan dengan penerapan Activity Based Costing System.

2. Hasil dari perhitungan yang dilakukan peneliti mengenai harga pokok sewa kendaraan menggunakan penerapan Activity Based Costing System ialah untuk jenis mobil Avanza Rp. 3.710.271 dan untuk jenis mobil Innova Rp. 6.567.413. Terdapat selisih harga yang terjadi pada jenis mobil Avanza yaitu Rp. 1.864.750 dan jenis mobil Innova yaitu Rp.1.313.328. Dalam penelitian ini, perhitungan menggunakan Activiy Based Costing memberikan hasil yang lebih rendah dibandingkan dengan perhitungan dari PT. Serasi Auotaraya.

\subsection{Saran}

Setelah membuat kesimpulan dari hasil penelitian ini, ada saran yang dapat disampaikan bahwa PT. Serasi Autoraya sebaiknya mencoba mempertimbangkan Activity Based Costing System dalam menghitung harga pokok jasa karena lebih sederhana dan akurat dalam menerapkan harga sewa, sehingga dapat membantu pihak manajemen dalam pengambilan keputusan yang tepat bagi perusahaan. Hasil perhitungan menggunakan $A B C$ System ini juga perpengaruh pada costumer yang ingin sewa kendaaran, dikarenakan harga sewanya lebih murah. Dan saran bagi peneliti selanjutnya untuk peneliti yang akan melakukan penelitian yang sejenis, diharapkan untuk meneliti beberapa perusahaan atau industri yang sejenis.

\section{DAFTAR PUSTAKA}

Carmelita, Carissa. 2017. Analisis Activity Based Costing System Dalam Penentuan Harga Pokok Produksi Guna Menentukan Harga Jual Gula (Studi Kasus pada PT. 
PG. Kebon Agung Unit PG. Kebon Agung Kecamatan Pakisaji Kabupaten Malang). Jurnal Administrasi Bisnis Vol. 48, No. 1. 2017. Malang: Fakultas Ilmu Administrasi Universitas Brawijaya.

Carter, Wiliam. 2013. Akuntansi Biaya. Buku Satu. Edisi keempat belas. Salemba empat : Jakarta.

Damayanyi, Rida A. 2017. Analisis Penerapan Metode Activity Based Costing Dalam Penentuan Tarif Harga Sewa Kamar Hotel. Jurnal Ilmiah Vol. 5, No. 1. 2017. Madiun: Pendidikan Akuntansi FKIP Universitas PGRI Madiun.

Dunia, Firdaus Ahmad., Abdullah, Wasilah. 2013. Akuntansi Biaya. Edisi Kedua. Salemba Empat, Jakarta.

Hansen, Don R. dan Mowen Marryanne M. 2013. Cornerstones of Cost Management. Cengange Learning.

Kamarrudin, Ahmad. 2013. Akuntansi Manajemen, Edisi Revisi, Cetakkan kedelapan. Raja Grafindo, Jakarta.

Kusuma, Zulkifli. Dan Sulastiningsih. 2013. Akuntansi Manajemen. Yogyakarta: EKONISIA.

Mulyadi. 2014. Activity-Based Cost System. Yogyakarta: UPP STIM YKPN.

Nailufar, Uyun. 2015. Penerapan Activity Based Costing System Dalam Menentukan Harga Pokok Jasa Rawat Inap (Studi pada RSUD Ibnu Kabupaten Gresik Tahun 2013). Jurnal Administrasi Bisnis Vol. 24, No. 1. 2015. Malang: Fakultas Ilmu Administrasi Universitas Brawijaya.

Romney, Marshal B. 2014. Sistem Informasi Akuntansi, Edisi ketigabelas, Diterjemahkan oleh: Kikin Sakinah, Nur Safira dan Novita Puspasari, Penerbit Salemba Empat, Jakarta.

Sugiyono. 2013. Metode Penelitian Bisnis (Pendekatan Kuantitatif, Kualitatif, Dan $R \& D$ ). Bandung : Alfabeta.

Wiratna, Sujarweni. 2014. Metodologi Penelitian. Yogyakarta: Pustaka Baru Press, 2014, hal. 30. 